\title{
Security for Show? The Militarisation of Public Space in Light of the 2016 Rio Olympic Games
}

\section{Veronica F. Azzi*}

\begin{abstract}
This article aims to analyse the increasing militarisation of public space in the Brazilian city of Rio de Janeiro, particularly on the eve of the 2016 Olympics. To this end, I briefly discuss how the concept of militarisation has been historically approached in the International Relations literature, namely within the security field. In the first section, I address the nature of the domestic security challenges Brazil faces as a developing country. In the second section, I show that the public security challenge of organised crime in Rio was securitised and confronted by increasing militarisation over the years as a result of a specific model of neo-liberal social control carried out by the country. I then analyse Brazil's Olympics security scheme carried out in order to portray Rio as a safe city to the world. In the last section, I highlight the contradictions between accounts on the collapse in domestic security vis-à-vis official government statements to the international media to assure that 'nothing would go wrong' during the mega sports event. The idea is to show how the militarisation of public security, rather than mere governmental efforts to signal stability to the international community during the Olympics, is a trend likely to outlast the event that implies not only, but mainly, the perpetuation of insecurity.
\end{abstract}

Keywords: (In)Security; Securitisation; Militarisation; Global Cities; Neo-liberalism; Rio 2016 Summer Olympics.

\section{Security and militarisation in International Relations}

After being central for many decades in International Relations literature, the concept of militarism became marginal in post-Cold War debates within the field, even in critical security studies. The assumption that central international insecurity challenges come from a weakening of the Weberian legitimate monopoly over violence (rather than the assertion or extension of state power) constitutes the source of current central challenges to human well-being and world order - be it internally, in cases of increasing civil violence and population displacement within failed states, or internationally, for instance, through * Pontifical Catholic University of Rio de Janeiro (PUC-Rio), Rio de Janeiro-RJ, Brazil; veniazzi@gmail.com.
ORCID iD 0000-0001-7811-4516. 
the use of ungoverned territories by drug cartels or international terrorists (Stavrianakes and Selby 2003: 7). In particular, the discourse based on the assumption that central international insecurity challenges would in fact come from a weakening of the Weberian legitimate monopoly over violence (rather than the assertion or extension of state power) constitutes what the central challenges to human well-being and world order presently derive from, 'whether this be internally, for example in increasing civil violence and population displacement within failed states, or internationally, for instance through the use of ungoverned territories by drug cartels or international terrorists' (Stavrianakes and Selby 2003: 7).

In a way, this concern stresses changes in the object of security, since a failed state not only would be unable to provide security to its citizens within its domestic territory, but most importantly, perhaps, could also itself be a source of insecurity for them. The shift from the state-centric model also represented a detachment from traditional core concerns - such as an excessive focus on arms influence, military institutions and ideologies, domestic/international politics - towards a broader concern, focused namely in 'the practice and legitimisation of exceptional "security" measures, performed either by the military, intelligence services, domestic law enforcement agencies, the media, or any number of state, private sector and international securitising actors' (Stavrianakes and Selby 2003: 10). Stavrianakes and Selby argue that due to these changes, military organisations, militarism, and militarisation outside the logic of war have not been studied much recently, although there is still much to be said about the many areas where security discourse has traditionally been applied (Stavrianakes and Selby 2003: 10).

When looking carefully at this shift in literature, this inclusion of new forms of agency and objects within the field which previously could not have been studied within the rationalist framework of analysis also resulted in a detachment from the topic of militarisation itself. But why is it that at the time of accounting for new forms of security we also have distanced ourselves from analysing militarisation and militarism, instead of incorporating these concepts into new forms of analysis? It seems to me that the difficulty in replying to this question reveals an epistemological limitation: an inability to conceive and understand the military as an institution in a way that is detached from its historical significance, that of being 'eternally' understood only in reference to the sovereign state. Only then would it be justifiable to speak of inter- and intra-state wars while also ceasing to consider the military, precisely because this concept is so ingrained in traditional war and security studies. This also highlights how in the literature we have mostly conceived the military as always directed outwards, to face outside threats, which represents the imaginary of the unstable dangerous international system as opposed to the assumption of a secure domestic order. This makes it extremely difficult to think of military action within the borders of a sovereign state, which is usually associated with the police. Sadly, this makes acknowledging all of the other forms in which the military engages in violence at the domestic level practically impossible to investigate as a worthwhile topic - especially in countries not considered as failed states, as is the case with Brazil. Thus, I argue that if we, as researchers, want to enhance the understanding of human security, then rethinking military engagement outside the logic of the sovereign nation state is not only important, 
but also extremely necessary if we are truly committed to conducting research that engages in understanding the ways through which violence is being increasingly exercised in the post-Cold War world.

For the reasons stated above, this article intends to demonstrate an empirical case of how militarisation is conceived outside the traditional understanding of the concept. In face of the urban insecurity problem in Rio, the Brazilian armed forces have been used to support and co-operate with the military police in operations to maintain and reproduce violent practices that involve enforcing repressive coercion. The military has also engaged in less coercive, albeit no less repressive, forms of social control that relate to the organisation of social life in certain areas where the military and police are being deployed. This is an effort to somehow transcend the logic of security as an essential value based on the idea of sovereignty of the state to allow for a better understanding of the term. Hence, we will adopt security as a complex, diffused expression of political, social, and economic powers of knowledge, representations, practices, and institutional forms that conceive, direct, and act over bodies and spaces, that is, as a political technology (Burke 2007: 28). Moreover, we will adopt a sociological conceptualisation of militarism (Shaw 2003: 19-0) which understands this phenomenon not in terms of strong war ideals, but rather because military relations affect social practices and social relations to a great extent (Shaw 2003: 19-0). Brazil inherited the institutional structures of a military regime that lasted for more than two decades (1964 to 1985). This deeply affected civilian-military relations in and of itself. One of many examples is the fact that to this day the police structure remains extremely militarised. The military police (PM), Special Forces such as the Batalhão de Forças Especiais (BOPE), and the National Public Security Force (Força Nacional) - created in 2004 - are predominantly composed of members of the military and military-trained officials. This peculiarity hinders differentiation of roles between members of security forces. One may argue that this entanglement facilitates what some authors have called the 'militarisation of law enforcement' even in the absence of ideological motivations (Stavrianakes and Selby 2003: 18).

\section{The nature of Brazil's security challenges}

In spite of its relative political stability, Brazil faces substantial domestic security issues such as the challenge of small arms, which affects many countries formally at peace albeit experiencing high levels of domestic and criminal violence (Bachelor and Kenkel 2014: 2). The country was ranked among the four most dangerous countries in the world in 2015, next to Colombia, Mexico, and Venezuela (Anistia Internacional 2016: 24). According to a report by the Forum of Public Security, more than 58,000 people were victims of homicide in Brazil in 2014, the number of dead police officers was 398, and more than 3,000 people were killed by the police - a 37\% increase when compared to 2013 (Anistia Internacional 2016: 82). The access to small arms is a clear indicator of the lack of control of coercive means by the Brazilian state: Between 1983 and 2003, the prevalence of such guns rose by 91.1 per cent, and the homicide rate by 111.7 per cent (Cerqueira and Pinho de Mello 
2014: 212). These numbers are comparable to official war zones and relate to the global development agenda issues of state fragility and armed violence (OECD 2008: 4).

Some authors have attributed the lack of means of coercion in developing countries to their historical trajectory of state formation. In such countries, no centralised institutions capable of imposing cohesion within the national territory and of guaranteeing the physical integrity of the state have emerged in the process of state formation, which could relate to the fragility, vulnerability, and security challenges they face (Dannreuther 2007: 308). It could also explain weak governance, limited institutional capacity, and result in a particular security orientation in which threats are understood mainly as internal instead of external, since political concerns originate, at times, not outside the state, but within society itself. Sometimes 'locations of authority in competition amongst themselves, are normally weaker than the state in terms of coercive capacity, but in terms of political legitimacy, and for large segments of the population, are equal or superior to the state' (Ayoob 1995: 4). In Rio, organised crime factions developed in mountainous areas that are difficult to access and hence were marginalised and neglected by the state (Fearon and Laitin 2004: 283). As the city developed, such areas underwent an urbanisation that lacked urban planning, security, and other basic services. This unregulated urbanisation process allowed parallel authorities and armed groups to seize the existing vacuum of power, transforming these areas into zones that are difficult to access - 'no-go zones' - where the presence of the state is limited, and its authority, little or absent (Williams 2003: 167).

The democratisation process in 1985 and a doctrine of non-interference in such neglected areas partly facilitated organised crime to further develop over time. During the 1980s and the 1990s, Latin America underwent a proliferation of neo-liberal adjustment policies that translated into a withdrawal of the state, progressive impoverishment, and informalisation of society, resulting in a social and political violence process that has endured over the decades despite the consolidation of formal democratic systems (Koonings and Kruijt 2004: 6). Not surprisingly, it was at that time that episodes of violence in the city started to become of national concern, precisely when political elites pursued a policy of punitive containment to complement the deregulation of the economy; for some, this was a shift from the penalisation to the militarisation of urban marginality (Wacquant 2008: 56). Residents of slums were treated as virtual enemies of the nation, tenuous trust in public institutions was undermined, and the spiral of violence accelerated, constituting an example of the full consequences of the penal disposal of a society swamped by social and physical insecurity (Wacquant 2008: 56). This entailed a paradox of deploying 'more state' in the realm of the police, criminal courts, and prisons to remedy the generalised rise of objective and subjective insecurity, which is itself caused by the neo-liberal doctrine of 'less state' (Wacquant 2008: 56). Similar accounts of violent efforts to maintain a neoliberal order also took place in South Africa after the apartheid regime, when the government decided to clean up the city from crime to attain world-class standards and to brand and market Cape Town to the world as a globally competitive city (Samara 2003: 277).

The securitisation of public insecurity to the point of justifying military deployment can also be understood in the overall understanding of security in South America. Even with the incorporation of the concept of human security into the regional security agenda, 
as observed in declarations adopted at the Special Conference on Security in Mexico in 2003, the focus of this concept remains squarely on the state (Herz 2010: 606). Analysis is centred on the state as object and actor, in terms of the notion of autonomy and reproducing the Westphalian system by stressing the division between the domestic and the international to reproduce the idea of a peaceful and stable region (Herz 2010: 602-603). According to Monica Herz, the diplomatic legalist tradition of advocating for peaceful conflict resolution and reinforcing sovereignty and non-intervention, largely supported by the academic, military, and diplomatic establishments, has become a constitutive element of the interpretation of international security in South America (Herz 2010: 608). Hence, the understanding of lawful, peaceful conflict resolution developed in the nineteenth century by South American elites concerned about their place in the international system of sovereign nation states acquired a new meaning: that of including conflicts with non-state actors and conflicts regarding control of the state (Herz 2010: 607).

For some, Latin America has undergone a substantial change in the nature of political violence in recent decades in that organised crime has gained increasing political influence due to its multiple and sophisticated capabilities to weaken state institutions and to become parallel powers in some marginal areas, even in the absence of political motivation and ideals (Ortiz 2015: 217). As such, maintaining a clear distinction between police and military roles has become increasingly unrealistic and problematic, since growth in crime rates has in many cases far surpassed the capabilities of police forces to restore order and seriously threatened governability in several instances (Norden 2015: 248). The 'easy' resort to violent militarised methods on the part of state authorities is particularly common in former military regimes that only recently transitioned to democracies, which is the case in most Latin American countries. Likewise, accusations of human rights violations at police-occupied sites, including charges of extrajudicial executions, alteration of crime scenes, criminalisation of victims by agents, and/or deaths justified as self-defence, are usually handled by the military due to the structure of the military police itself, meaning that the few cases that are investigated usually follow military protocol and end up unaccountable.

Civil society organisations attribute the increasing militarisation in Brazil to weak and corrupt security and justice systems that lack resources and political will to ensure independence and impartiality, which has sustained a culture of impunity to the extent that authorities have appealed to militarised answers to face social and political problems (Anistia Internacional 2016: 84). Others argue that a demilitarisation of the police would help curb the exacerbated violence in terms of the worrisome way public security has been conducted in the country (El País 2016).

\section{Securitising organised crime: The Police Pacifying Units (UPPs)}

Public insecurity and violence in Rio is an ongoing challenge commonly referred to as a war by government authorities, but it was not until the 2000s that this issue became a top priority on Brazil's national security agenda. In 2008, shortly after FIFA announced that Brazil would host the 2014 World Cup, both the federal government and the state 
of Rio de Janeiro announced the implementation of a new public security program in Rio: the Police Pacifying Units, also known as the UPPs. At the inauguration of the first UPP, President Luiz Inácio Lula da Silva and the Rio state governor Sérgio Cabral publicly framed the acts of organised crime as acts of terrorism (Bravo and Drumond 2014: 218). By securitising the issue, they classified the crisis in public security in Rio as an existential threat (Buzan et al 1998: 25) of high priority and relative to survival, thus justifying a heavy military intervention with the use of the armed forces to support police action. The UPP as a policy was meant to recover physical control of some territories occupied by organised crime, since 'former policies had allowed alternative authorities traditionally opposed to the state to develop there' (Institute of Public Security of Rio de Janeiro; author's translation). The purpose was to reclaim sovereignty in such spaces, establishing greater presence of the state. The official discourse framed public (in)security in Rio as an utmost priority in the national security agenda and made the case to deploy the armed forces, whose role, a priori, is to maintain domestic integrity and to protect against external threats. The rhetoric of securitisation of organised crime observed in the UPPs is clear in its reference to the term 'pacification', a concept that is, in itself, an allusion to war. Pacification references a colonising process or a military operation whose goal is to assure the peaceful co-operation of a population within a designated area (Neocleous 2014: 33). As such, pacifying is a social role exercised by the police targeting a population to put forward practices that enable the construction of a productive social order associated with keeping the peace and ensuring security (Neocleous 2014: 34).

In fact, when implemented for the first time in 2008, the UPP was not solely a geographically targeted policy as part of preparing Brazil for the World Cup and, later, for the Olympics. It was also a long-term strategy of liberal social control in that it targeted populations, individuals, and spaces in particular ways, namely by means of a highly selective allocation of coercive social control, encompassing the everyday policing of the racialised poor and managing protests (Kienscherf 2016: 1180). Interpreted that way, the UPPs are not violent only in terms of the element of coercive use of force. Another kind of violence is present in the goal of regaining control of the state, a violence that meant incorporating traditionally excluded regions to establish power over them, making them integrated and productive. The official discourse on the Institute of Public Security of Rio de Janeiro (Instituto de Segurança Pública do Rio de Janeiro - ISP) website defines 'special areas of the city as areas inhabited by low-income populations with low levels of predominance of state institutions and a high level of economic informality, where the opportunist presence of drug dealers defies the ability of the government to keep the rule of law' (Institute of Public Security of Rio de Janeiro; author's translation). The official slogan of the policy is 'UPP: it came to stay', whose promise is to promote security, citizenship, and social inclusion, providing the local population with the peace and public security necessary to the full exercise of citizenship, and ensuring socio-economic development. The rhetoric of war against crime portrays this challenge as a major obstacle to development, whose underlying assumption is the belief that social development cannot be achieved without security. 
It is there to be noticed that the UPP as a policy not only represents occupation on the part of the state. It is also designed to integrate such formerly excluded areas through the exercise of greater control of such populations in their everyday lives. As such, we can relate it to a model of bio-politics in that the organisation of social life is made evident by the state's control of human life (Foucault 2007: 440). Hence, the occupation taking place here is not exclusively territorial; there is also a genuine interest in the lives of the inhabitants of those social spaces. Their activities and what they do for a living should be no less productive to the state. Among the many mechanisms of social control to make such lives a differential and constitutive element in the development of its forces are efforts to counter economic informality such as making the legalisation of services and rents mandatory, requiring permits for street vendors, and building agencies to provide social security and work documentation.

\section{Framing national security: The ongoing war against crime}

The problem of security in Brazil has been associated with the idea of 'citizen security', which, in theory, should reflect a more democratic and community-oriented approach (Cano 2006: 137). Due to the crisis in public security, however, there has been a demand observed since the year 2000, when the National Public Security Plan was launched, that the federal government take a more active role (Cano 2006: 138). In practice, however, formulating security policies at the federal level resulted in a detachment from the discourse of citizen security. Instead, it meant using war as a metaphor and as a reference for public security operations with militarised structure, doctrine formation, strategy, and tactics (Cano 2006: 141). At first, the armed forces' involvement with and support of the UPPs was justified with the reasoning that high militarised coercion was necessary to confront and remove well-established organised crime. Subsequently, however, physical occupation of UPP sites by military police was only made possible with the support of the armed forces. This is how the supposedly temporary joint effort response to (in)security issues became a permanent condition over time. One year before the Summer Olympics, it was estimated that more than 2,000 homicides took place in Rio in 2015 alone, many of the victims dying as a result of shootings between the police and members of criminal associations, or by extrajudicial attacks and incursions by the police (BBC 2016). That same year, a UNICEF report stated that 28 people under 19 were killed per day in the country; Brazilian authorities denied these numbers, claiming that the state of Rio had actually reduced the number of child and adolescent homicides between 2000 and 2013 (Telesur TV 2015). Also in 2015, the Vice-President of the UN Committee on the Rights of the Child Renate Winter acknowledged that, although violence in Brazil was not new, it had become more prominent in Rio with the goal of 'present[ing] a problem-free city to the world' (Telesur TV 2015). She also accused the Brazilian police of assassinating street children systematically as part of an effort to 'clean the streets' for the Olympics (Telesur TV 2015). In July 2015, Brazil announced that it would present a concrete national plan for the reduction of homicides, but that never happened. Perhaps to avoid criticism and divert attention from the issue, the country decided not to apply for re-election to the UN 
Human Rights Council. (Anistia Internacional 2016: 82). Instead, a few months later, in October, the Brazilian Senate approved the first antiterrorism law in the country, which defined the practice of terrorism as 'any act which seriously attempts to disrupt the stability of the democratic state, aiming to subvert the functioning of its institutions' (Folha de São Paulo 2015; author's translation). By granting the state a prerogative to act in the name of democracy to protect stability, even if that means using violence at the expense of human security to enforce it, the new piece of legislation is a clear sign of how public security issues became part of the Brazilian 'national security agenda', so to speak.

One could argue that this systematic engagement with violence resembles Charles Tilly's definition of violent rituals, since it involves specialists of a highly co-ordinated group whose agents compete for priorities in certain areas, exercising monitoring and surveillance, and following a ritual with the purpose of inflicting damage (Tilly 2003: 82). There is violence resulting from the interaction, albeit not in a generalised way; rather, it is contained within the limits or intersections of such socially activated borders recognised by all parts involved, a logic that takes form by means of a mobilisation of 'us' versus 'them'. The inflicted damage is expected to occur in the established delimitations in a somewhat co-ordinated way, like contained versions of a war (Tilly 2003: 86, 87). The military has allegedly been deployed to use violence to suppress popular manifestations of protest with excessive or unnecessary force, although its frequent involvement has mainly been to engage with and respond to the rising influence of organised crime networks (Anistia Internacional 2016: 26). In an episode in the Maré favela in Rio, one of the first UPP sites, a young man was shot allegedly by the armed forces as a result of the incident and no full and impartial investigation was made (Anistia Internacional 2016: 83). According to Amnesty International, the army had been playing a police role in the community since 2014, and although soldiers were designated to act in the Maré only before the World Cup and should have left the site afterwards, they 'continued to perform policing roles in the community until June 2015, period, during which inhabitants accused the military of a great number of human rights violations, such as physical violence and firing against residents (Anistia Internacional 2016: 83). There is much controversy in how Brazil chooses to handle human rights criticism. How could it be possible to reconcile the image of a global South rising power despite so many domestic security challenges, given that confronting them compromises human security and violates humanitarian ideals? Yet, if we take a closer look, we see that the country has put together a discourse through which it portrays itself to the world in a rather coherent narrative. In 2011, the then police reform leader Ignacio Cano promised a revolutionary transformation in the security sector, proclaiming a wholly new repurposed police force to end trafficking-related violence, the aim of which was not so much to win the unwinnable 'war on drugs', but to protect the population instead (Amar 2013: 8). This marked more involvement of the military in the security forces. In 2012, Brazil's Minister of Defence stated that the military in Rio constituted the greatest law and order enforcement operation ever realised by the armed forces following the strictest constitutional principles and extended at the request of the entire Federation to allegedly promote human security (Amar 2013: 11). These efforts meant that UPP officers (be it military police or members of the armed forces) would serve as domestic peacekeep- 
ers in communities targeted for Olympic redevelopment, drawing from their experience leading the United Nations Stabilization Mission in Haiti (Amar 2013: 10, 12). This stance adopted by Brazil is what Paul Amar has called a post-neo-liberal human-security democracy regime, which takes place in global South megalopolises such as Rio that are not necessarily better than neo-liberal regimes, nor more consensus-based or less coercive, but whose focus is to humanise military police and the police security apparatus to secure cultural heritage and developmental infrastructure (Amar 2013: 15-16). Their aim would be to respond to the crumbling legitimacy of neo-liberalism's laissez-faire policies and financial infrastructures, as well as to backlash against neo-conservatism's wars on terror, and its disregard for human rights (Amar 2013: 14). Whatever the official discourse, what we observe in practice is how, by deploying military practices and solutions to address its inherent challenges to confront the problem of public insecurity, Brazil ends up reproducing precisely what it seems to be trying to avoid: the perpetuation of even more violence and the creation of an overall sense of insecurity.

\section{The Olympics as a violent endeavour?}

When Brazil was selected to host the Summer 2016 Olympic and Paralympic Games, the International Olympic Committee (IOC) decision took into account the geographical factor of having a South American city host the mega sports event for the first time, which was intended to spark the interest of the entire continent and help Brazil develop faster (New York Times 2009). Mega events have long been regarded as one of the hallmarks of modernity, since they have managed to integrate industrial and corporate interests with those of government as marketing for tourism, as well as for wider urban and regional development strategies (Hall 2016: 59). Rio's candidacy aimed to accelerate its development and promote greater integration and better living standards for its residents and whose legacy should outlast the event (Rio de Janeiro City Hall 2016). According to the mayor Eduardo Paes, the Olympics would enable the government to execute past building projects that would serve to enhance urban mobility, revitalise certain areas, help flood control, and expand sanitation infrastructure, besides helping to reduce social cleavages and better integrate the city's regions, which would allow the city, and ultimately, the country, to achieve its long-term global aspirations (Rio de Janeiro City Hall 2016).

In addition, sports mega events have become particularly integral to the entrepreneurial strategies of cities seeking to gain competitive advantage in the global economy (Hall 2016: 67). IOC's former President Jacques Rogge stated that 'Rio presented a strongly technical proposal based in the vision that the games would be a celebration of athletes and of sports, while at the same time offering the city, the region and the country the opportunity to meet its broader long-term future aspirations', as made clear in the city's candidacy slogan: Rio2016, the 'Games of celebration of transformation' (Rio de Janeiro City Hall 2016). Following the decision, former President Luiz Inácio Lula da Silva stated with enthusiasm: 'I never felt so proud of Brazil before. Now, we are going to show the world that we can be a great country. We are not the United States of America, but we are 
getting there, and we will get there' (New York Times 2009). Hosting the Olympics meant a new era to the city, a promise of prosperity, inclusion, and political projection. Nevertheless, such aspirations, brought up in the report of the IOC Evaluation Commission on the candidate cities' official propositions, also raised questions as to whether it would be feasible for a developing country like Brazil to effectively host the Olympics. In the report, IOC's concerns were mainly over urban challenges related to the environment, infrastructure, and security. One of them was that the country could be overwhelmed after hosting the Military Games in 2011 and the World Cup in 2014, to which Brazil responded that Rio annually receives two million people during Carnival and New Year's Eve celebrations (Report of the 2016 IOC Evaluation Commission 2007). However, security has always been the most pressing IOC concern. The committee stated that 'Rio recognises that it faces security challenges and that it is carrying out an ambitious project to ameliorate the resources, the technology and the training of its police force up to 2012' (Report of the 2016 IOC Evaluation Commission 2007). In response, a presentation of the Brazilian National Public Security Secretary highlighted advances in public security and a reduction in crime achieved in Rio in previous years by means of a change in approach, including programmes of policing communities and social programmes with sports activities to reduce crime, enhance the participation of young people in sport, and foster integration in less favoured areas of the city (Report of the 2016 IOC Evaluation Commission 2007) - a clear reference to the UPPs. Yet, years later, Rio's commitment to the international community proved hard to keep. On the eve of the 2016 Summer Olympics, Brazil no longer enjoyed the economic prosperity that it did in 2009. Instead, the country was facing one of its worst political and economic crises ever. Amid political crisis following the impeachment of president Dilma Rousseff, the interim government of Michel Temer threatened to reduce investments; additional issues such as environmental and health concerns over pollution and the Zika virus kept coming up in the press, and the overall perception was that Brazil was not handling them effectively (The Chicago Tribune 2016b). In face of the many doubts over its capacity to fulfil the promise of improvements made to the IOC, international perception continued to be central to Brazil's concerns (Huffington Post 2016). Upon criticism over unfinished public transportation sites, Rio's City Hall rushed to meet the delivery deadline, publishing an evaluation report in English entitled 'Games on Time', which listed all Olympic public planning, explaining and showing the projects that were finished or in a concluding phase, such as the bus and the subway extensions, urban sanitation projects, and the construction of stadiums in 'nomad architecture' style to easily serve as schools after the event (Rio de Janeiro City Hall 2016).

However, nearly a month ahead of the Olympics, Rio's mayor asked the Brazilian federal government to deploy the military to assist in the enforcement of public security during the event. In an interview with $\mathrm{CNN}$, Paes expressed dissatisfaction with the fact that security was Rio's major concern, that 'the state government was doing "a terrible job" on the eve of the Olympics, and that luckily the city would not have to rely solely on the military police for security, since federal government had granted funds to ensure the proper functioning of public services and enforce public security' (CNN 2016). In June of 2016, amid financial and logistic difficulties due to cuts in the state budget and officers not 
receiving salaries (The Guardian 2016), the Rio governor declared financial emergency, requesting federal government support to avoid 'a complete collapse in public security, health, education, transportation and environment,' a political move which allowed the state to receive direct federal budget approval without having to undergo standard legislative procedure (Folha de São Paulo 2016a; author's translation). Police strikes and protests over insecurity and the death of several police officers created additional tension. Many inhabitants of occupied areas such as the Complexo do Alemão and Maré worried that after the Olympics the government would stop the pacification programmes and that the police would cease to occupy and leave, especially due to the return of drug trafficking and organised crime to sites where the pacifying project, formerly considered a success, had been undergoing frequent shootings and attacks on UPP units (BBC 2016b). In spite of this, the government was to contain the violence from confrontations within slums from spilling over to neighbouring areas, many of which were well-to-do neighbourhoods where the games were scheduled to take place (BBC 2016c).

On the one hand, the overall perception of insecurity ahead of the Games was handled with more militarisation. Outsourced security companies were contracted and established checkpoints and scheduled constant patrolling of Olympic venues and neighbouring sites, along with the armed forces. Military exercises, somewhat analogous to army parades, were practised frequently and openly to the public. All this did not stop a few foreign athletes from getting robbed in the city, but even then, interim president Michel Temer wrote an open letter to the media with the assurance that Brazil was indeed ready to host the event after all, given that the country had put together a solid security scheme to ensure the peace and tranquillity of athletes and visitors, and reminding his audience that Brazil had vast experience in hosting mega events of international scale like the World Cup and the Pan-American Games and 'awaited visitors with arms wide open, since another success was yet to come' (BBC 2016a). On the other hand, Brazilian authorities also redirected the public's attention towards the issue of international terrorism. In an event held by the Council of Americas in June 2016, the organising chief of the Olympic Committee in Brazil reiterated that terrorism was 'his priority above all other security challenges' (The Chicago Tribune 2016a). Brazil had declared it would put into practice more rigid measures in search of any possible gaps in its Olympics security scheme following the Nice terrorist attacks in July 2015 (Bloomberg 2016). Since the country's 16,000 kilometres of porous borders made it an easy target to attacks, Rio would have an antiterrorism centre co-operating with international intelligence agencies, as well as double the contingent of London in 2012: 85,000 members of combined Brazilian security forces, of which more than 40 per cent comprised members of the military (Bloomberg 2016). In July 2016, the biggest terrorist simulation ever conducted in Brazil was carried out to prepare for the Olympics; more than 1,000 men from combined security forces participated, including members of the army, air force, navy, Força Nacional, all three police branches (military, civilian, and federal), and intelligence; the official in charge, General Mauro Sinott of the Joint Command for Preventing and Combating Terrorism, regarded the military exercise as 'positive, and yet another opportunity to keep the capacity of our forces up to date' (Jornal Nacional 2016; author's translation). By July, eleven individuals suspected of planning 
a terrorist attack on the Olympic Games were arrested in so-called Operation Hashtag on charges of having ties to Islamic State (O Globo 2016). The arrests, headed by the federal police, mobilised 130 police officers in ten different Brazilian states; allegedly, the individuals had been being monitored by social media since 2015 and had planned to buy an AK-47 online to engage in terrorist acts (G1 Notícias 2016). Although launched officially on the eve of the Olympics, Operation Hashtag was created following suspicions of an alleged Islamic State cell in Brazil and involved the co-operation of the National Brazilian Intelligence Agency (ABIN), Brazilian Federal Police, the armed forces and international intelligence agencies. Investigations were made possible following approval of an amendment to the antiterrorism act in March 2016, sanctioned by the executive branch of government, allowing the arrest of 'anyone who may represent harm to public security with the attempt of provoking social or generalised terror' (Correio Braziliense 2016, author's translation). Since their preventive arrest, not much of the case has been mentioned; perhaps not surprisingly, the issue seemed to lose visibility once the Olympics ended.

\section{The face of militarisation in Brazil}

Despite all preparations for the Olympics to handle the apparent threat of terrorism, during the course of the mega sports event, an officer of the National Security Force was shot on 11 August after accidentally entering the Vila do João slum in the Maré complex. Up to that moment, two episodes had caused the National Force to start escorting official Olympic cars. The first was when police found rifle projectiles next to Olympic sites; the second, when a bus of journalists was attacked next to Olympic venues. After the incident, the Brazilian Minister of Defence Raul Jungmann lamented the death of the officer in the Maré and promised that necessary measures would be taken, albeit assuring that this accident was not to be interpreted in a way as to diminish the security efforts of the Olympics security scheme. He hence assured the public that, in spite of this incident, there was 'no doubt that Rio was still a safe city' (Folha de São Paulo 2016c; author's translation). However, what seemed to be an isolated episode of violence brought to light once again the existing concern that criminality was a greater preoccupation to Brazil than the threat of terrorism at the Olympics. The army retaliated by surrounding and prohibiting access to such areas to stop criminals from leaving them, which was then followed by major incursions by police special forces and the federal police, actions that, according to the minister, would serve as an example 'to show that criminality would not be tolerated' (Folha de São Paulo 2016b; author's translation). In the following days, the police and the military carried out more combined operations in the area, this time to arrest drug dealers and apprehend drugs, some of which even had the Olympic logo printed on their package in order to be sold by the drug dealers at the event (Folha de São Paulo 2016d).

Although at first glance, government efforts seemed to be targeted towards security during the Olympics, the rhetoric of the city's war against crime soon re-emerged even in declarations aimed at such apparently isolated acts. Following the Maré accident, the Brazilian Minister of Justice promised that his office would provide all logistical and operational support to the effort of fighting arms and drug trafficking, and that he would enact 
future decrees to facilitate the execution of such measures, at least one of which should include allowing the use of apprehended heavy arms in combat actions by the police to enable greater agility and capacity of response (Folha de São Paulo 2016d). On 18 August, the Brazilian Minister of Defence Raul Jungmann announced that the arrangement of 23,000 officers from the armed forces, National Security Forces and the military police deployed to the event would be maintained with few reductions at least until the state elections in October (O Povo 2016). Although not explicitly acknowledged in his statement, it is clear that the point of keeping this extra deployment of officers in the streets was to enforce public security.

Even before the end of the global mega sports event, official responses to and public statements about this problem ceased to be enacted by more internationally well-known figures, such as the head of the executive or specialised agencies aimed at co-operating over security issues such as terrorism, as was the case before the inauguration of the event. Instead, the involvement of figures like the Minister of Justice and the Minister of Defence in the issue of Rio's public security - a task previously implemented at the state level highlights a more active stance on the rhetoric of the war against crime in Brazil, which once again became increasingly domestically oriented. It also shows how authorities of increasingly higher hierarchies are making the case for increasing militarisation, framing it more and more as the only feasible and necessary means of handling the violence in the city. So in a way, this militarisation went along with the increasing securitisation of public security: the more insecurity became a matter of national priority, the more militarised the proposed measures of the federal government to face it became, despite this taking place in Rio as a global city. In February 2017, soldiers were still patrolling public sites and their involvement with policing was scheduled to continue at least up to March (UOL Notícias 2017a). One might argue that the presence of the military in common public spaces ranging from traditional tourist areas like Copacabana beach to main highways such as Avenida Brasil, and the interaction between armed forces officials with the population in everyday life outside of the Olympics context, raises important questions for future reflection, such as what perceptions citizens have of them, which is puzzlingly positive.

Conversely, while the military was patrolling the streets until at least March 2017, Civilian Police Special Operations Force (CORE) took part in violent incursions in Maré in order to fight drug trafficking (O Globo 2017). At first sight, the involvement of the civilian police could be seen as a sign of less violent practices, given that they are usually less violent than the military police and the armed forces. Yet, a more active involvement of civilian police in drug trafficking incursions - a responsibility normally outside its jurisdiction - could just as well be another sign of rising militarisation in that it is an action that implies a redefinition of police roles. In March 2017, the deterioration of security in Rio was such that after many past denials, the state itself acknowledged that the number of deaths caused by the police had grown by $120 \%$ in the past 5 years, numbers comparable to the period before the first police pacifying program was implemented (UOL Notícias 2017b). Deaths of underpaid military police officers also entered the statistics, and the state and city of Rio both continue to face financial crisis; in a way, this facilitated justify- 
ing the deployment of agents paid directly by the federal government, that is, armed forces personnel.

This is the face of militarisation in Brazil: police working in conjunction with the military in an enterprise in which their roles seem to be increasingly similar. Armed forces acquire policing roles, and the line between the military and police is a grey and a fine one. This is due to many aspects, some of which I tried to analyse in this article. To mention a few, one could highlight the military structure of the Brazilian security forces and the securitisation of organised crime in the city as part of a long-term development programme to eradicate crime and 'pacify' specific areas of the city to enhance forms of neo-liberal social control by the Brazilian state. This enterprise seems to have failed to decrease violence, bringing even greater insecurity instead.

\section{Conclusion}

This paper highlighted the efforts of the Brazilian government to assure the international community that its biggest weakness - security - would not be an issue during the Olympics since it would be compensated for by extra military deployment - a common practice in Brazil also observed in previous events such as the Pan-American Games and the World Cup. However, I tried to show that, other than being a mere government effort to provide security for the mega sports event as an isolated action, militarisation in Brazil today is an integral part of the country's law enforcement which closely relates to current understandings of national security in Brazil and its exercise of sovereign control. We can then conclude that even though the Olympics may have in some ways affected and contributed to the increasing violence in the city, militarisation in Brazil today constitutes a practice on which Brazil's global aspirations seem to rely and, as such, will not decline in future years.

As this article was being written, Roberto Sá, a former member of the military and federal police forces who co-ordinated the UPPs project, was appointed the new Secretary of Security of the state of Rio de Janeiro. This appointment is a political move that highlights the deeper involvement of militarised aspects in the state's security apparatus, and points to further radicalisation in security policies. My analysis has tried to show how the public security policy in Brazil, relying on militarised practices, is a case that perpetuates violence at the expense of human security. It argues we need to reflect on the social and political consequences of this model and reconsider it to understand how human insecurity is being reproduced by such violent practices in the name of sovereignty.

\section{References}

Anistia Internacional. 2016. Anistia Internacional Informe 2015/16: O Estado dos Direitos Humanos no Mundo. At https://anistia.org.br/wp-content/uploads/2016/02/Informe2016_Final_Web-1.pdf [Accessed on 20 July 2016]. 
Amar, Paul. 2013. The Security Archipelago: Human-Security States, Sexuality Politics, and the End of Neoliberalism. Durham: Duke University Press.

Ayoob, Mohammed. 1995. The Third World Security Predicament: State Making, Regional Conflict and the International System, London: Lynne Rienner.

Batchelor, Peter and Kai Michael Kenkel (eds). 2014. Controlling Small Arms: Consolidation, Innovation and Relevance in Research and Policy. New York: Routledge.

BBC News [online]. 2016a. 'Rio 2016: Brazil's interim leader Michel Temer dismisses worries'. 5 July. At http://www.bbc.com/news/world-latin-america-36714637 [Accessed on 30 July 2016].

. 2016b. 'Rio 2016: Violence seeps back into city’s favelas'. 20 July. At http://www.bbc.com/ news/world-latin-america-36849995 [Accessed on 20 July 2016].

2016c. 'Rio Olympic Games: Concerns about Violence in Host City'. 20 July. At http:// www.bbc.com/news/av/world-latin-america-36849175/rio-olympic-games-concern-about-violence-in-host-city [Accessed on 25 July 2016].

Bloomberg [online]. 2016. 'Brazil Beefing up Rio Olympic Security after France Attack'. 15 June. At http://www.bloomberg.com/news/articles/2016-07-15/brazil-reviewing-rio-olympic-securityafter-france-terrorattack [Accessed on 20 July 2016].

Bravo, Barbara and Paula Drumond. 2014. 'Challenging Modernities in Rio de Janeiro: A Critical Analysis of the "Pacification" Project'. In Peter Batchelor and Kai Michael Kenkel (eds), Controlling Small Arms: Consolidation, Innovation and Relevance in Research and Policy. New York: Routledge, pp. 218-235.

Burke, Anthony. 2007. Beyond Security, Ethics and Violence: War Against the Other. Routledge Advances in International Relations and Global Politics. London: Routledge.

Buzan, Barry, Ole Waever and Jaap de Wilde. 1998. Security: A New Framework of Analysis. Boulder: Lynne Rienner.

Cano, Ignacio. 2006. 'Políticas de segurança pública no Brasil: Tentativas de modernização e democratização versus a guerra contra o crime'. SUR: Revista Internacional de Direitos Humanos, 5: 136-155.

Cerqueira, Daniel Ricardo de Castro and João Manuel Pinho de Mello. 2014. 'Firearms and crime in Brazil'. In Peter Batchelor and Kai Michael Kenkel (eds), Controlling Small Arms: Consolidation, Innovation and Relevance in Research and Policy. New York: Routledge, pp. 201-217.

CNN [online]. 2016. 'Rio mayor: State doing a 'terrible, horrible job' before Olympics'. 5 July. At http://www.cnn.com/2016/07/04/americas/rio-olympics-mayor-police/ [Accessed on 20 July 2016].

Correio Braziliense [online]. 2016. 'Lei antiterror segue para sanção de Dilma: Entenda o que foi aprovado'. 25 February. At http://www.correiobraziliense.com.br/app/noticia/politica/2016/02/25/ internas_polbraeco,519279/lei-antiterror-segue-para-sancao-de-dilma-entenda-o-que-foi-aprovado.shtml [Accessed on 21 May 2016].

Dannreuther, Roland. 2007. 'War and Insecurity: Legacies of Northern and Southern State Formation'. Review of International Studies, 33: 307-326.

El País [online]. 2016. 'O que pensa a única mulher a comandar uma Secretaria de Segurança no Brasil'. 13 July. At http://brasil.elpais.com/brasil/2016/07/04/politica/1467663009_176394.html?id_ externo_rsoc=FB_CC [Accessed on 20 July 2016]. 
Fearon, James D and David Laitin. 2004. 'Why Do Some Civil Wars Last So Much Longer Than Others?' Journal of Peace Research, 41 (3): 275-301.

Folha de São Paulo [online]. 2015. 'Senado aprova lei antiterrorismo; proposta voltará à Câmara'. 28 October. At http://www1.folha.uol.com.br/poder/2015/10/1699904-senado-aprova-lei-antiterrorismo-proposta-voltara-a-camara.shtml [Accessed on 22 July 2016].

2016a. 'Rio decreta calamidade pública por crise financeira e Olimpíadas'. 17 June. At http://www1.folha.uol.com.br/mercado/2016/06/1782893-rio-decreta-calamidade-publicapor-crise-financeira-e-olimpiada.shtml [Accessed on 20 June 2016].

2016b. 'Morre agente de segurança da Olimpíada baleado após entrar em favela por engano' 12 August. At http://www1.folha.uol.com.br/esporte/olimpiada-no-rio/2016/08/1802013morre-agente-de-seguranca-da-olimpiada-baleado-apos-entrar-em-favela-por-engano.shtml [Accessed on 14 September 2016].

2016c. 'Morte de soldado não deslustra a Olimpíada do Rio de Janeiro.' 12 August. At http://www1.folha.uol.com.br/esporte/olimpiada-no-rio/2016/08/1802130-morte-de-soldadonao-deslustra-a-olimpiada-do-rio-de-janeiro-diz-temer.shtml [Accessed on 14 September 2016].

2016d. 'Reação ao ataque contra Força Nacional já matou quarto e feriu cinco no Rio'. 16 August. At http://www1.folha.uol.com.br/esporte/olimpiada-no-rio/2016/08/1803757-reacao-aoataque-contra-forca-nacional-ja-matou-quatro-e-feriu-cinco-no-rio.shtml [Accessed on 14 September 2016].

Foucault, Michel. 2007. Security, Territory, Population. New York: Palgrave.

G1 Notícias [online]. 2016. 'PF acionou 130 policiais em 10 Estados para prender suspeitos.' 22 July. At http://g1.globo.com/bom-dia-brasil/noticia/2016/07/pf-acionou-130-policiais-em-10-estadospara-prender-suspeitos.html [Accessed on 30 December 2016].

Hall, C. Michael. 2006. 'Urban entrepreneurship, corporate interests and sports mega-event: the thin policies of competitiveness within the hard outcomes of neoliberalism.' The Sociological Review, 54 (2): 59-70.

Herz, Monica. 2010. 'Concepts of Security in South America'. International Peacekeeping, 17 (5): 598-612.

Huffington Post [online]. 2016. 'Everything is Going Wrong in Brazil Ahead of the Olympics. 23 May. At http://www.huffpostbrasil.com/entry/rio-olympics-2016-brazil-crises_ us_573b53e7e4b0646cbeeb02c8 [Accessed on 7 August 2016].

Institute of Public Security of Rio de Janeiro (ISP). At http://www.upprj.com/ [Accessed on $20 \mathrm{Au}-$ gust 2015].

International Olympic Committee. 2007. Report of the 2016 IOC Evaluation Commission. At https:// stillmed.olympic.org/media/Document\%20Library/OlympicOrg/IOC/Olympic_Games/Olympic_ Games_Candidature_Process/Past_Candidature_Processes/2016_Host_City_Election/EN_2016_ Evaluation_Commission_report.pdf [Accessed on 20 June 2016].

Jornal Nacional [online]. 2016. 'Militares fazem maior simulação antiterrorismo para a Olimpíada'. 16 July. At http://g1.globo.com/jornal-nacional/noticia/2016/07/militares-fazem-maior-simulacaoantiterrorismo-para-olimpiada.html [Accessed on 22 July 2016].

Kienscherf, Markus. 2016. 'Beyond Militarization and Repression: Liberal Social Control as Pacification'. Critical Sociology, 42 (7-8): 1179-1194. 
Koonings, Kees and Dirk Kruijt (eds). 2004. Armed Actors: Organized Violence and State Failure in Latin America. London: Zed Books.

Neocleous, Mark. 2014. War Power, Police Power. Edinburgh: Edinburgh University Press.

New York Times [online]. 2009. 'Rio Wins 2016 Olympics in a First for South America'. 2 October. At http://www.nytimes.com/2009/10/03/sports/03olympics.html?_r=2 [Accessed on 15 July 2016].

Norden, Deborah L. 2015. 'Latin American Militaries in the $21^{\text {st }}$ Century: Civil-military relations in the era of disappearing boundaries'. In David R Mares and Arie M Kacowicz (eds), Routledge Handbook of Latin American Security, Abingdon and New York: Routledge, pp. 242-253.

O Globo [online]. 2016. 'Veja quem são os suspeitos de planejar ataque na Olimpíada'. 22 July. At http://g1.globo.com/rio-de-janeiro/olimpiadas/rio2016/noticia/2016/07/veja-quem-sao-os-presossuspeitos-de-planejar-ataque-na-olimpiada.html [Accessed on 30 December 2016].

2017. 'Polícia faz Operação no Complexo da Maré. 29 May. At http://oglobo.globo.com/ rio/policia-faz-operacao-no-complexo-da-mare-10765192 [Accessed on 15 March 2017].

O Povo [online]. 2016. 'Ministro da Defesa diz que vai manter Força Nacional no Rio após as Olimpíadas'. 18 August. At http://www.opovo.com.br/app/maisnoticias/mundo/ae/2016/08/18/noticias ae,3649492/ministro-da-defesa-diz-que-vai-manter-forca-nacional-no-rio-apos-olimp.shtml [Accessed on 20 September 2016].

Organisation for Economic Cooperation and Development (OECD). 2008. Concepts and Dilemmas of Statebuilding in Fragile Situations: From Fragility to Resilience. Paris: OECD.

Ortiz, Román D. 2015. 'Guerrillas, Terrorists, or Criminals? The new face of antistate violence in Latin America'. In David R Mares and Arie M Kacowicz (eds), Routledge Handbook of Latin American Security. Abingdon and New York, pp. 210-220.

Rio de Janeiro City Hall. 2016. Rio 2016: Olympics and Legacy: Quick Guide to Public Policies. At http://www.rio.rj.gov.br/dlstatic/10112/4379008/4129850/RIO2016_estudos_ING.pdf [Accessed on 10 August 2016].

Samara, Tony Roshan. 2003. 'State Security in Transition: The War on Crime in Post Apartheid South Africa'. Social Identities, 9 (2): 277-312.

Shaw, Martin. 2003. 'Twenty-First Century Militarism: A Historical Sociological Framework'. In Anna Stavrianakes and Jan Selby (eds), Militarism and International Relations. London: Routledge, pp. 19-32.

Stavrianakes, Anna and Jan Selby (eds). 2003. Militarism and International Relations. London: Routledge.

Telesur TV [online]. 2015. 'UN Body Accuses Brazil's Military Police of Killing Kids to 'Clean Streets' for the Olympics'. 13 October. At http://www.telesurtv.net/english/news/UN-Brazils-PoliceKill-Kids-to-Clean-Streets-for-Olympics-20151013-0044.html [Accessed on 22 July 2016].

Tilly, Charles. 2003. The Politics of Collective Violence. New York: Cambridge University Press.

The Chicago Tribune [online]. 2016a. 'Rio CEO: Security is biggest concern for Olympics'. 28 June. At http://www.chicagotribune.com/sports/international/ct-security-biggest-concern-rio-olympics20160628-story.html [Accessed on 20 June 2016].

2016b. 'Rio de Janeiro is not Ready for the Olympics, and the IOC is to Blame. 15

July. At http://www.chicagotribune.com/sports/international/ct-rio-de-janeiro-olympics-ioc20160715-story.html [Accessed on 20 July 2016]. 
The Guardian [online]. 2016. 'Welcome to Hell: Rio Police Protest Financial Disaster ahead of Olympic'. 28 June. At https://www.theguardian.com/sport/2016/jun/28/rio-olympics-safety-security-budgets-cut [Accessed on 28 June 2016].

UOL Notícias [online]. 2017a. 'Presença de Militares muda Cenas no Cotidiano do Rio de Janeiro'. 15 February. At https://noticias.uol.com.br/album/2017/02/15/presenca-de-militares-muda-cenasdo-cotidiano-do-rio-de-janeiro.htm\#fotoNav=6 [Accessed on 10 March 2017].

2017b. 'Número de Mortos pela Polícia no Rio cresce'. 9 March. At https://noticias.uol. com.br/cotidiano/ultimas-noticias/2017/03/09/numero-de-mortos-pela-policia-no-rio-cresce120-em-5-anos-e-beira-tempos-pre-upp.htm [Accessed on 14 March 2017].

Wacquant, Loïc. 2008. 'The Militarization of Urban Marginality: Lessons from the Brazilian Metropolis'. International Political Sociology, 2: 56-74.

Williams, Phil. 2003. 'Transnational organized crime and the state'. In Rodney Bruce Hall and Thomas J Biersteker (eds), The emergence of private authority in global governance. Cambridge: Cambridge University Press, pp.161-182.

\section{About the author}

Veronica F. Azzi is a $\mathrm{PhD}$ candidate at the Institute of International Relations at the Catholic University of Rio de Janeiro (PUC-Rio), Brazil. She holds an MA in International Politics and Public Policy from the University of California, San Diego (UCSD) and a BA in International Relations from PUC-Rio. Her interests include security, gender, state fragility, instability and political violence, militarisation, and security policies. She has worked at the University of California, Los Angeles (UCLA) as a Research Associate, where she co-authored articles on juvenile incarceration and youth protection initiatives, such as for a joint research project to advocate for a safe harbour law in California to protect young females arrested on charges of prostitution.

\section{Segurança à Mostra? A Militarização do Espaço Público à Luz dos Jogos Olímpicos de 2016 no Rio}

Resumo: Este artigo pretende analisar a crescente militarização do espaço público na cidade brasileira do Rio de Janeiro, particularmente às vésperas dos Jogos Olimpícos de 2016. Para tanto, discuto brevemente como o conceito de militarização foi historicamente abordado na literatura de Relações Internacionais, especificamente no campo da segurança. Na primeira seção, abordo a natureza dos desafios de segurança doméstica que o Brasil enfrenta enquanto país em desenvolvimento. $\mathrm{Na}$ segunda seção, mostro que, ao longo dos anos, o desafio da segurança pública para o crime organizado no Rio foi securitizado e acompanhado por uma crescente militarização resultante da adoção de um modelo específico de controle social neoliberal 
no país. Em seguida, analiso como o esquema de segurança dos Jogos Olímpicos do Brasil visou retratar o Rio como uma cidade segura para o mundo. Na última seção, destaco as contradições entre diferentes concepções acerca do colapso da segurança interna vis-à-vis as declarações oficiais do governo para a mídia internacional, de modo a garantir que "nada daria errado" durante o megaevento esportivo. Argumento que, ao invés de meros esforços governamentais para difundir a ideia de estabilidade para a comunidade internacional, a militarização da segurança pública constitui uma tendência que deve se estender para além dos Jogos Olímpicos, e cujas implicações incluem não apenas, mas principalmente, a perpetuação da insegurança.

Palavras-chave: (In)Segurança; Securitização; Militarização; Cidades Globais; Neoliberalismo; Jogos Olímpicos Rio 2016.

Received on 11 August 2016, and approved for publication on 31 May 2017.

\section{(c)) BY-NC}

https://creativecommons.org/licenses/by-nc/4.0/ 